\title{
REGENERASI DENDRIT SEL GANGLION RETINA: PERAN INSULIN UNTUK MENGEMBALIKAN PENGLIHATAN PADA GLAUKOMA
}

\author{
Nurul Azizah ${ }^{1}$, Sisca $^{2}$, Rasiha $^{3}$ \\ 1,2,3 Universitas Hasanuddin \\ e-mail: azizahsasa9@gmail.com
}

\begin{abstract}
Glaukoma is a leading cause of irreversible blindness worldwide. This disease is associated with characteristic damage to the optic nerve and permanent retinal ganglion cell (RGC) degeneration. A crucial step towards circuit repair in glaucoma is to promote damaged RGCs to regenerate not only axons, but also dendrites to successfully reconnect with their synaptic partners. The latest research showed that insulin signalling has the capacity to regenerate dendrites dan injured synapses, therefore the use of insulin raises a new paradigm as a new pro-regenerative therapeutic target for the disease of glaucoma.
\end{abstract}

This literature review is made using literature searching of valid journals with inclusion and exclusion criteria. On the experiment of insulin's effectivity, it is valued using 4 indicators; promote dendrite regeneration, restore synaptic density, rescue retinal function, robust neuronal survival. Based on in vivo experiment, insulin endowed with the ability to effectively restore dendritic morphology thus enhancing the function and survival of RGC through mTORC1 (mammalian target of rapamycin complex 1) and mTORC2 (mammalian target of rapamycin complex 2) signalling, this supports that that it can be promising therapeutic targets to counter progressive $R G C$ neurodegeneration and vision loss in glaucoma.

Keywords $\quad$ : Dendrites, Glaucoma, Insulin, RGCS

\begin{abstract}
Abstrak
Glaukoma masih menjadi penyebab utama kebutaan permanen di seluruh dunia. Penyakit ini berkaitan dengan kerusakan saraf optik serta kerusakan sel ganglion retina (retinal ganglion cell, RGC) yang tidak dapat diperbaiki. Salah satu langkah krusial yang berperan dalam pengobatan glaukoma adalah mendorong regenerasi RGC, tidak hanya terhadap akson, tetapi juga dendrit agar sel tersebut dapat menyambung kembali dengan pasangan sinaptiknya. Penelitian terbaru menunjukkan adanya pensinyalan insulin yang memiliki kapasitas untuk meregenerasi dendrit dan sinapsis setelah cedera, sehingga penggunaan insulin memunculkan paradigma baru mengenai terapi pro-regeneratif pada penyakit ini. Literature review ini disusun menggunakan metode studi pustaka dengan mengumpulkan jurnal valid dengan kriteria inklusi dan eksklusi khusus.

Dalam pengujian efektivitasnya, digunakan 4 indikator yaitu pengaruh insulin terhadap peningkatan regenerasi dendrit, pengembalian synaptic density, penyelamatan fungsi retina, dan peningkatan kelangsungan hidup neuron. Berdasarkan hasil pengujian secara in vivo, insulin mampu mengembalikan morfologi dendritik dan meningkatkan fungsi dan kelangsungan hidup RGC melalui pensinyalan mtorc1 (mammalian target of rapamycin complex 1) dan mtorc2 (mammalian target of rapamycin complex 2), sehingga dapat menjadi terapi pro-regeneratif yang menjanjikan alam neurodegenerasi RGC yang progresif dan mengembalikan penglihatan pada glaukoma.
\end{abstract}

Kata kunci : : Dendrit, Glaukoma, Insulin, RGCs 


\section{PENDAHULUAN}

Glaukoma adalah penyebab utama kebutaan permanen di seluruh dunia dan dikaitkan dengan kerusakan pada saraf optik dan pola hilangnya bidang visual karena degenerasi sel ganglion retina (RGC). Diperkirakan lebih dari 60 juta orang di seluruh dunia dengan neuropati optik glaukoma dan 8,4 juta di antaranya kehilangan penglihatan secara permanen. Insiden global glaukoma diperkirakan akan meningkat menjadi 76 juta pada tahun 2020 dan 111,8 juta pada tahun 20401. Glaukoma merupakan penyebab kebutaan ireversibel atau permanen yang dicirikan dengan rusaknya sel ganglion retina yang tidak dapat diperbaiki ${ }^{2}$.

Kehilangan RGC telah diidentifikasi sebagai bentuk paling awal dari kematian sel pada glaukoma, dan pengurangan fungsi RGC yang pada akhirnya dianggap bertanggung jawab atas hilangnya bidang visual. Retina manusia mengandung sekitar 1,5 juta RGCs dengan perkiraan tingkat kehilangan RGC sebesar $0,4 \%$ per tahun karena penuaan fisiologis normal dan meningkat menjadi $4 \%$ per tahun pada pasien glaukomal. Strategi neuroprotektif diselidiki secara ekstensif dalam konteks gangguan neurologis, dan membentuk terapi paradigma yang bertujuan memperlambat atau mencegah kematian neuron ${ }^{3}$. Terapi neuroprotektif harus meningkatkan kelangsungan hidup RGC. Beberapa pendekatan untuk perlindungan saraf pada glaukoma sedang diselidiki dengan menargetkan penarikan neurotropik, toksisitas excito, stres oksidatif, disfungsi mitokondria, dan folding protein ${ }^{4}$. Sebuah langkah penting menuju perbaikan pada glaukoma adalah untuk mendorong regenerasi dari akson RGC yang rusak dan juga mendorong dendrit untuk dapat berhasil menyambung kembali dengan mitra sinaptiknya. Paradoksnya, meskipun banyak yang diketahui tentang regenerasi aksonal, kapasitas RGC yang terluka untuk meregenerasi dendrit telah diabaikan ${ }^{5}$.

Mempromosikan kelangsungan hidup RGC adalah langkah penting dalam pengembangan menuju strategi perlindungan saraf ${ }^{6}$. Namun, akson RGC dalam glaukoma mengalami kerusakan dan dengan demikian terapi glaukoma neuroprotektif yang ideal tidak hanya merangsang kelangsungan hidup RGC tetapi juga harus merangsang regenerasi akson ${ }^{7}$. Aplikasi klinis yang telah ada masih belum optimal untuk mengatasi kerusakan akson $^{8}$. Pensinyalan insulin yang tidak tepat atau tidak cukup, dikaitkan dengan degenerasi saraf pada penyakit yang ditandai oleh patologi dendritik ${ }^{9}$. Pada sebuah penelitian oleh Jessica Agostinone et al. tahun 2018 menunjukkan bahwa neuron dalam sistem saraf pusat mamalia memiliki kapasitas intrinsik untuk meregenerasi dendrit dan sinapsis setelah cedera, dan memberikan alasan kuat untuk penggunaan insulin dan/atau analognya sebagai terapi pro-regeneratif untuk penyakit neurodegeneratif yang tidak terobati termasuk glaukoma.

\section{HASIL DAN PEMBAHASAN}

\section{Dendrit Sel Ganglion Retina}

Hilangnya penglihatan pada glaukoma disebabkan oleh kematian sel ganglion retina (RGC) yang tidak dapat dipulihkan. Dendrit RGC adalah substrat yang berfungsi untuk menerima input sinaptik ${ }^{10}$. Stabilitas struktural dari anyaman dendritik penting dalam fungsi normal RGC dan kemampuannya untuk mengirimkan informasi visual. Dendrit merupakan kompartemen seluler khusus yang sangat istimewa karena mempengaruhi cara neuron 
mengumpulkan dan memproses informasi. Selama proses visualisasi normal, dendrit sel ganglion retina (RGC) menerima input sinaptik dari sel bipolar dan amakrin di lapisan pleksiformis bagian dalam. Informasi ini terintegrasi, diproses, dan dikirim melalui akson RGC di saraf optik ke pusat penglihatan di otak ${ }^{11}$. Integritas struktural dendrit sangat penting untuk penglihatan. Dendrit memungkinkan komunikasi antara RGC dan neuron retina lainnya melalui sinapsis.

Pada glaukoma, degenerasi RGC yang progresif menyebabkan kehilangan penglihatan. Kepala saraf optik (Optik Neuron Head, ONH) telah diidentifikasi sebagai titik utama kerusakan aksonal awal pada glaukoma. Cedera akson RGC memicu perubahan cepat dalam dendrit. Perubahan patologis dalam dendritik RGC meliputi retraksi cabang, pengurangan kompleksitas, dan kehilangan sinapsis. Retraksi dendritik dan hilangnya sinapsis mencegah konektivitas sel-sel dan transmisi saraf sehingga berkontribusi terhadap kematian RGC dan defisit visual permanen.

\section{Insulin dan Perannya terhadap Regenerasi Dendrit}

Keberadaan Insulin yang tidak tepat atau tidak cukup, bahkan tanpa adanya diabetes, telah dikaitkan dengan degenerasi saraf pada penyakit yang ditandai dengan patologi dendritik. Secara umum, insulin hanya dipandang sebagai hormon yang bekerja di perifer, namun, ternyata insulin juga melewati sawar darah otak dan memengaruhi proses-proses fisiologis otak seperti transimisi antarneuron, pertahanan neuron, serta penampilan kognitifnya. Tidak adanya hormon ini, baik akibat penyakit diabetes atau karena penyebab lain, akan menimbulkan masalah terkait degenerasi neuron. Hal ini telah dibuktikan oleh beberapa penelitian, bahwa tidak adanya insulin berhubungan dengan penyakit-penyakit degenerasi neuron khususnya pada dendrit, seperti penyakit alzheimer, parkinson, dan glaukoma.

Proses insulin dapat memengaruhi regenerasi neuron dimulai saat insulin berikatan pada reseptornya, yang kemudian akan mengaktivasi phosphoinositide-3 kinase $(\mathrm{PI} 3 \mathrm{~K})^{19}$. Pada proses pengikatan insulin terhadap reseptor serta fosforilasinya, terdapat regulator penting yang dikenal sebagai mammalian target of rapamycin (mTOR). mTOR sendiri merupakan enzim kinase yang berperan mengatur sintesis protein serta pertumbuhan sel. Secara khusus mTOR terdiri atas dua tipe yaitu mTOR complex 1 (mTORC1) dan mTOR complex 2 (mTORC2), yang masing-masing memiliki peran tersendiri ${ }^{20}$ mTORC1 utamanya diinduksi oleh kadar energi. Enzim ini utamanya berperan pada proses pertumbuhan dan metabolisme sel seperti proses sintesis protein, lemak, dan nukleotida, serta menghambat proses katabolisme sel. Sedangkan mTORC2 yang diinduksi oleh faktor pertumbuhan, selain berperan pada proses fosforilasi dan pengikatan insulin ke reseptor, juga berperan pada fosforilasi dan aktivasi Akt. setelah teraktivasi, maka Akt akan mempertahankan sel, merangsang proliferasi, serta pertumbuhan sel ${ }^{20,21,22}$. Hal inilah yang menjadi dasar dalam proses regenerasi neuron.

\section{Uji Efektivitas Insulin}

Untuk menguji efektivitas insulin dalam regenerasi dendrite $\mathrm{RGC}$, Polo dkk. menggunakan dua metode pendekatan terhadap tikus yang menjadi hewan coba, yaitu model glaukoma dan aksotomi. Model glaukoma direkayasa dengan membuat tikus mengalami 
hipertensi intraokular yang diikuti dengan peningkatan tekanan intraokular. Sedangkan, aksotomi ialah suatu transeksi komplet pada nervus optikus untuk memicu hilangnya RCG dengan cepat. Analisis pada model glaukoma dilakukan pada minggu ke-2 setelah hipertensi okular diinduksi dengan injeksi microbeads intracameral untuk melihat kerusakan yang ditimbulkan. Setelah itu, diberikan insulin setiap hari (selama 1 minggu) melalui injeksi intraperitoneal hingga pada minggu ke-3, dilakukan analisis kembali untuk melihat efek dari pemberian insulin tersebut. Pada model akosotomi, analisis dilakukan tiga hari setelah mengalami kerusakan aksonal (aksotomi). Setelah itu diberikan insulin selama 4 hari melalui injeksi intraperitoneal atau topikal (tetes mata) hingga pada hari ke-7, dilakukan analisis kembali untuk melihat efek dari pemberian insulin tersebut. Dalam melakukan penelitian tersebut, Polo dkk. membandingkan kelompok hewan coba yang diberikan pengobatan dengan insulin dan kelompok yang diberikan phosphate-buffered saline (PBS/Vehicle) sebagai kelompok kontrol. Hasil dari penelitian tersebut menunjukkan:
1. Insulin meningkatkan regenerasi dendrit

Regenerasi dendrit dilihat dengan menggunakan dua indikator, yaitu gambaran neuron dan analisis kuantitatif. Gambaran neuron pada hari ketiga menunjukkan RGC memiliki anyaman dendrit yang tampak lebih kecil dan sederhana dibandingkan dengan neuron yang utuh dan tidak terluka (Gambar A dan B). Gambaran analisis pada hari ketujuh menunjukkan anyaman dendrit kelompok kontrol tidak menghasilkan perbaikan (Gambar C), berbeda dengan gambaran dendrit RGC dengan intervensi insulin yang justru menunjukkan perbaikan yang signifikan bahkan hampir sama dengan neuron yang utuh (Gambar D). Indikator yang kedua, yaitu analisis kuantitatif dari parameter dendritik juga tampak menunjukkan hasil yang berbanding lurus, di mana neuron yang diobati dengan insulin memiliki dendrit yang lebih panjang dan anyaman yang lebih besar serta lebih kompleks daripada kontrol (PBS). Demikian pula, pemberian insulin sistemik setelah mengalami hipertensi okular menghasilkan regenerasi anyaman dendrit yang signifikan. Sedangkan, dendrit RGC pada kelompok kontrol tidak mengalami regenerasi (Gambar EG). 


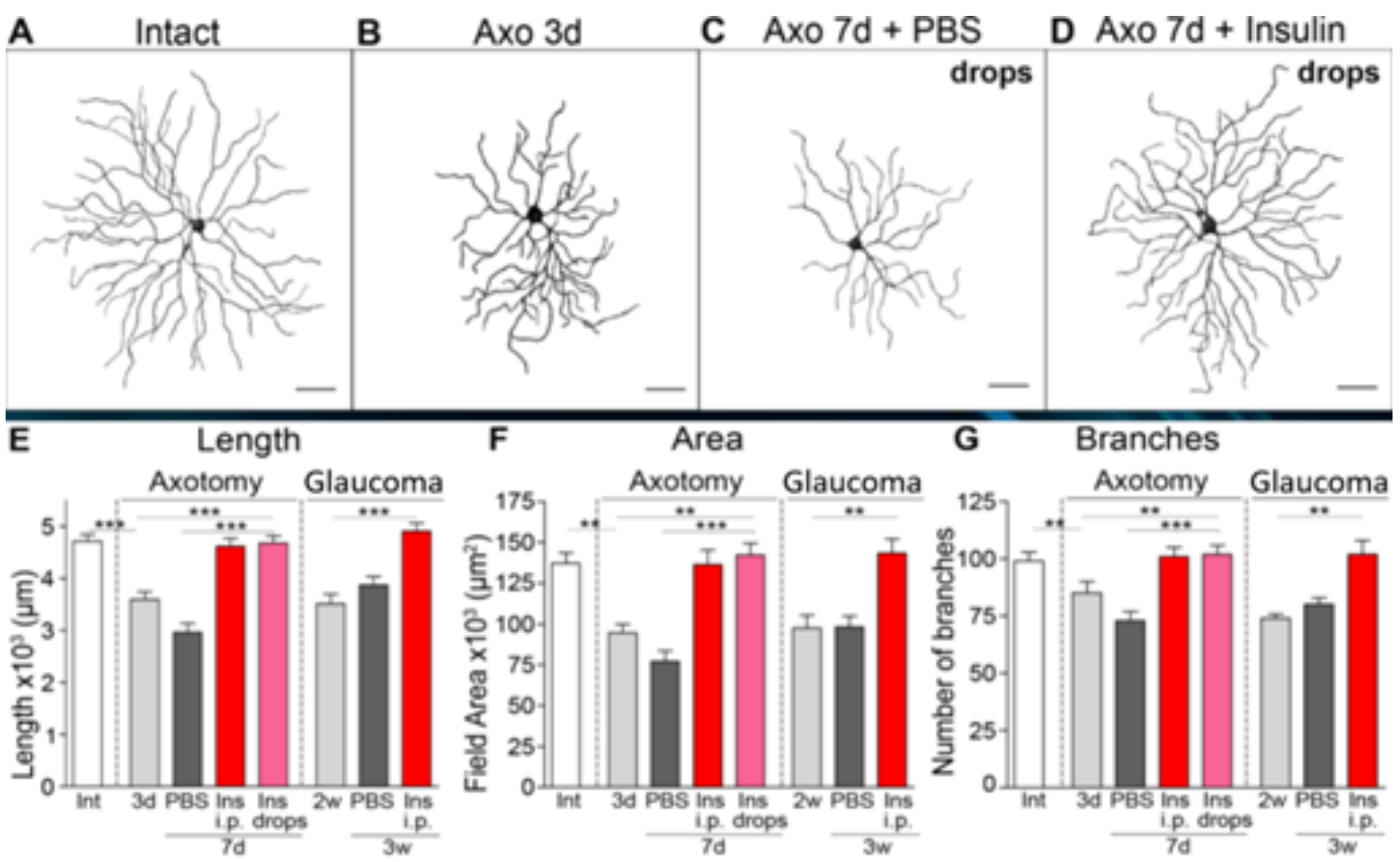

Gambar 1. Regenerasi dendritik pada RGC dewasa setelah mengalami cedera aksonal.

Catatan : (A) Gambaran anyaman dendrit retina utuh (intact) dan tidak terluka. (B) Gambaran anyaman dendrit 3 hari setelah aksotomi. (C) Gambaran anyaman dendrit 7 hari setelah aksotomi + PBS. (D) Gambaran anyaman dendrit 7 hari setelah aksotomi + insulin. (E) Analisis kuantitatif panjang dendrit. (F) Analisis kuantitatif luas dendrit. (G) Analisis kuantitatif cabang dendrit. ). Data disajikan dengan rata-rata \pm S.E.M. (ANOVA, *: $\mathrm{p}<0,05, * * ; \mathrm{p}<0,001$, $* * * ; \mathrm{p}<0,0001, \mathrm{~N}=4$ hingga 6 tikus $/$ grup, $\mathrm{n}=28$ hingga $46 \mathrm{sel} /$ grup). Scale bars: $25 \mu \mathrm{m}$ (semua panel).

Singkatan : Ins, Insulin; i.p, intraperitoneal.

2. Insulin mengembalikan Synaptic Density

Input eksitasi dari sel bipolar ke RCG terjadi di ribbon synapse, stuktur khusus yang memungkinkan pengiriman neurotransmisi cepat dan berkelanjutan yang diperlukan untuk penglihatan. Untuk mengetahui apakah insulin mampu mengembalikan Glutametargic synapse ini, Polo dkk. meneliti perubahan vesicular glutamate transporter 1 (VGLUT1), protein presinaptik yang diekspresikan pada ribbon synapse bipolar dan postsynaptic density protein 95 (PSD95) pada lapisan plexiform dalam (inner plexiform layer, IPL) dimana dendrit RCG berada. Penurunan signifikan ekspresi VGLUT1 dan PSD95 terjadi setelah kerusakan aksonal pada kelompok kontrol (Gambar A dan B) sedangkan pada kelompok dengan insulin menunjukkan pemulihan sempurna VGLUT1 dan PSD95 (Gambar C). Temuan yang sama juga didapatkan pada tikus dengan hipertensi okular di mana pemberian insulin mengembalikan synaptic density dibandingkan dengan kelompok kontrol. Analisis kuantitatif pre dan postsynaptic voxels (mengukur volume 3D pada IPL yang ditempati oleh VGLUT dan PSD95) juga mengkonfirmasi bahwa insulin mendorong regenerasi synaptic density (Gambar D dan E). 


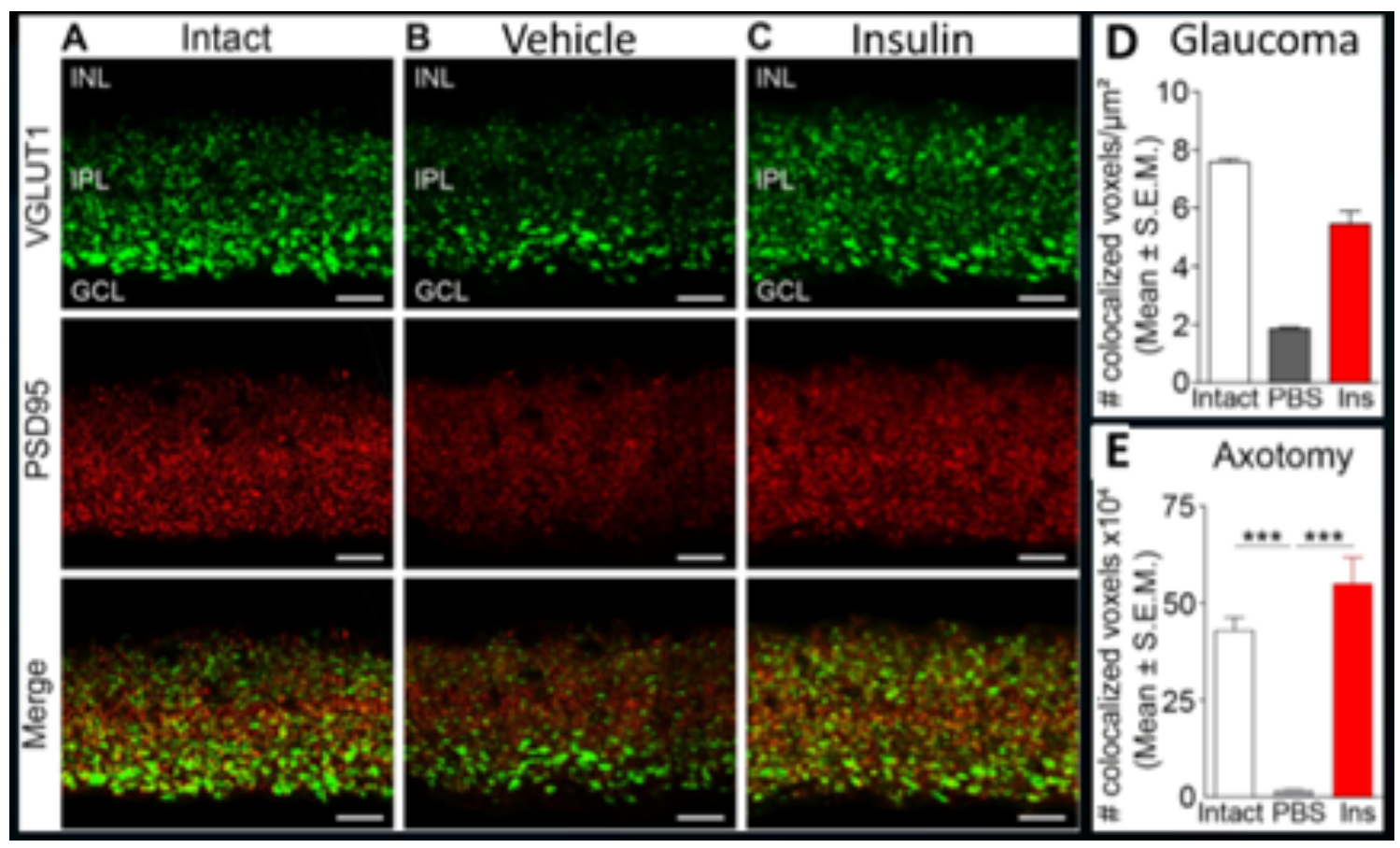

Gambar 2. Insulin mengembalikan glutametargic postsynaptic site pada neuron yang rusak.

Catatan : (A) Glutamatergic sunapses yang divisualisasikan pada IPL intact menggunakan imunolabelling VGLUT1 (hijau) dan PSD95 (merah). (B) Glutamatergic sunapses yang divisualisasikan pada IPL kelompok kontrol. (C) Glutamatergic sunapses yang divisualisasikan pada IPL kelompok dengan insulin. (D) Analisis kuantitatif pada model glaukoma. (E) Analisis kuantitatif pada model aksotomi. Data disajikan dengan rata-rata \pm S.E.M. (ANOVA, $* * *=p<0.001, \mathrm{~N}=4-6$ tikus/grup). Scale bars: $10 \mu \mathrm{m}$

Singkatan : INL: inner nuclear layer, IPL: inner plexiform layer, GCL: ganglion cell layer.

\section{Insulin menyelamatkan fungsi retina}

Untuk Untuk menilai dampak insulin pada dendrit dan regenerasi sinaps terhadap fungsi RGC, dilakukan pengukuran terhadap dua komponen dengan menggunakan electroretinogram (ERG). Respon ERG direkam dengan menstimulasi retina dengan intensitas cahaya berkisar antara $10^{-6}$ dan $10^{-4} \mathrm{~cd} \mathrm{~s} / \mathrm{m} 2$ untuk positive scotopic threshold response (pSTR), dan $10^{2}$ cd $\mathrm{s} / \mathrm{m} 2$ untuk photopic negative response ( $\mathrm{PhNR})$. $\mathrm{pSTR}$ dan PhNR sebagian besar berasal dari aktivitas RGC di retina tikus, dan berkurang setelah nervus optikus rusak dan/atau mengalami glaukoma. Gambar
5 menunjukkan rekaman pSTR dan PhNR pada retina utuh (Gambar A dan D, warna hitam), setelah diterapi dengan PBS/vehicle (Gambar B dan E, warna biru), dan insulin (Gambar $\mathrm{C}$ dan F, warna merah), serta pada mata kontralateral tikus yang tidak mengalami kerusakan retina (noninjured animals, warna abu-abu). pSTR dan PhNR menurun pada kelompok tikus +PBS dengan penurunan amplitude $48 \%$ dan $60 \%$ dibandingkan dengan kelompok pre-injury. Sebaliknya, kelompok insulin justru mengalami perbaikan secara utuh yang menunjukkan pemulihan dari fungsi RGC terhadap stimulasi cahaya. 


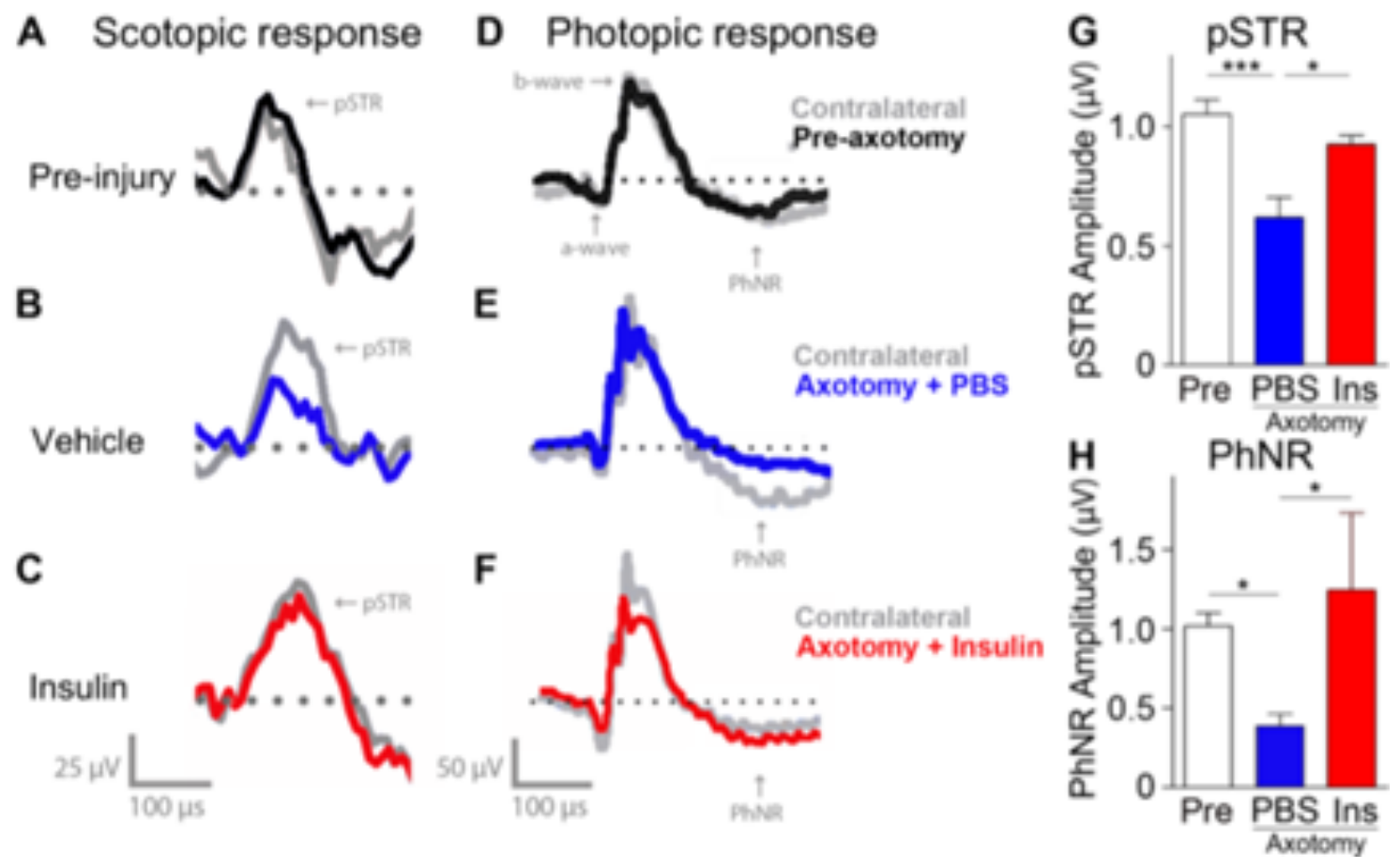

Gambar 3. Insulin menyelamatkan fungsi retina setelah aksotomi nervus optikus.

Catatan : (A-F) Rekaman ERG yang ditimbulkan oleh stimulasi cahaya scotopic (A-C) dan photopic (DF) sebelum aksotomi, dan setelah aksotomi dengan PBS serta insulin. $(\mathrm{G}, \mathrm{H})$ Analisis kuantitatif dari amplitudo pSTR dan. Data disajikan dengan rata-rata \pm S.E.M. (ANOVA, ${ }^{* *}=\mathrm{p}<0.01,{ }^{*}=\mathrm{p}<0.05, \mathrm{~N}=4-6$ tikus/grup).

Singkatan : pSTR: positive scotopic threshold response, PhNR: photopic negative response.

4. Kelangsungan hidup neuron meningkat pesat

Untuk mengetahui apakah efek proregeneratif dari insulin juga menunjukkan kemampuan RGC untuk bertahan setelah mengalami kerusakan, penelitian Polo dkk. berlanjut dengan mengikuti pengobatan yang sama seperti sebelumnya (insulin) dan menganalisis neuronal density di retina pada minggu ke-1 dan 2 setelah aksotomi dan minggu ke-3 setelah mengalami hipertensi okular. Retina dari mata yang diobati dengan insulin secara konsisten menunjukkan densitas yang lebih tinggi atas RBPMS (RNAbinding protein with multiple splicing, selective marker dari RCG) dibandingkan dengan kelompok kontrol (Gambar A-C). Analisis kuantitatif juga menunjukkan kelangsungan hidup RCG yang lebih baik pada tikus dengan terapi insulin dibandingkan dengan kontrol pada minggu ke-1 (insulin: 70\% survival, $\mathrm{PBS}: 46 \%$ survival) dan minggu ke 2 (insulin: 60\% survival, PBS : 14\% survival) setelah aksotomi. 


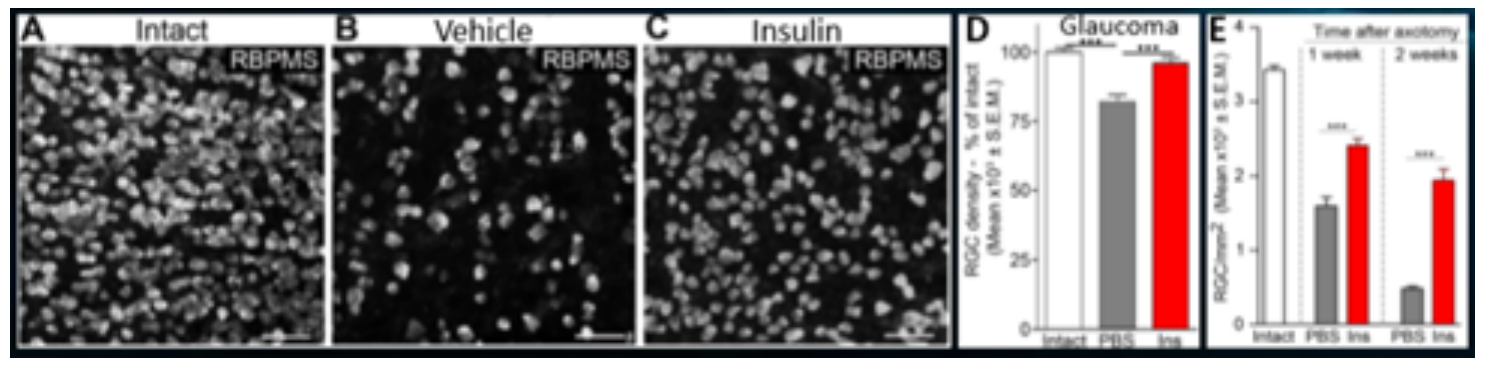

Gambar 4. Insulin mendorong neuroproteksi RGC setelah rusaknya akson.

Catatan : (A-C) Flat-mounted retinas eyes. (D-E) Analisis kuantitatif densitas RCG. Data disajikan dengan rata-rata \pm S.E.M. (ANOVA, $* * *=p<0.001, * *=p<0.01, *=p<0.05, n=5-6$ tikus/grup).

Singkatan : RBPMS: RNA-binding protein with multiple splicing.

\section{KESIMPULAN DAN SARAN}

\section{Kesimpulan}

RGC memiliki kemampuan untuk meregenerasi dendrit dan sinapsis secara efektif setelah mengalami kerusakan. Insulin mampu berperan sebagai strategi yang kuat dalam mengembalikan morfologi dendritik dan meningkatkan fungsi dan kelangsungan hidup RGC melalui pensinyalan mTORC1 dan mTORC2. Data penelitian ini mendukung penggunaan insulin dan analognya sebagai target terapi pro-regeneratif yang berpotensi dalam pengobatan neurodegenerasi RGC yang progresif dan mengembalikan penglihatan pada glaukoma.

\section{Saran}

Perlunya dilakukan penelitian lebih lanjut menggunakan metode ini dengan pengujian klinis pada subjek manusia untuk melihat efektivitas dan efek samping yang akan terjadi, serta untuk menilai apakah terdapat korelasi antara progresivitas glaukoma dan pengobatan insulin pada pasien yang mengalami diabetes.

\section{DAFTAR PUSTAKA}

1. Tham Y-CC, Li X, Wong TY, Quigley HA, Aung T, Ed F, Cheng CY (2014) Global Prevalence of Glaucoma and Projections of Glaucoma Burden through 2040. A Systematic Review and MetaAnalysis. Ophthalmology 121:2081-2090. doi: 10.1016/j.ophtha.2014.05.013

2. Quigley HA, Broman AT. The number of people with glaucoma worldwide in 2010 and 2020. Br J Ophthalmol. 2006;90(3):262-267.

3. Quigley, 1458 H.A., 2011. Glaucoma. Lancet 377 (9774), 1367-1377.

4. Baltmr, A., Duggan, J., Nizari, S., Salt, T.E., Cordeiro, M.F., 2010. Neuroprotection in glaucoma-Is there a future role? Exp. Eye Res. 91 (5), 554-566.

5. Agostinone J, Alarcon-martinez L, Gamlin C, Yu W, Wong ROL, Polo A Di. Insulin signalling promotes dendrite and synapse regeneration and restores circuit function after axonal injury. 2018;

6. Wie 1608 rzbowska, J., Robaszkiewicz, J., Figurska, M., Stankiewicz, A., 2010.Fu 1609 ture possibilities in glaucoma therapy. 
Med. Sci. Monit. 16 (11), R 1610 A252-RA259.

7. Krupin, T., Liebmann, J.M., Greenfield, D.S., Ritch, R., Gardiner, S., 2011. A random-ized trial of brimonidine versus timolol in preserving visual function: results from 1301 the Low-Pressure Glaucoma Treatment Study. Am. J. Ophthalmol. 151 (4), 671-681.

8. Sarah Q. Progress in Neurobiology Towards axonal regeneration and neuroprotection in glaucoma: Rho kinase inhibitors as promising therapeutics. Prog Neurobiol [Internet]. Elsevier Ltd; 2015;1-15. Available from: http://dx.doi.org/10.1016/j.pneurobi o.2015.06.002

9. Kweon JH, Kim S, Lee SB. The cellular basis of dendrite pathology in neurodegenerative diseases. BMB Reports 2017; 50: 5-11.

10. Ward, N.J., Ho, K.W., Lambert, W.S., Weitlauf, C., Calkins, D.J., 2014. Absence of transient receptor potential vanilloid-1 accelerates stress-induced axonopathy in the optic projection. J. Neurosci. 34, 3161-3170.

11. Masland, R.H., 2012. The neuronal organization of the retina. Neuron 76, 266-280.

12. Nickells, R.W., Howell, G.R., Soto, I., John, S.W.M., 2012. Under pressure: cellular and molecularresponses during glaucoma, a common neurodegeneration with axonopathy. Annu.Rev. Neurosci. $35,153-179$.

13. Morgan, J.E., 2012. Retina ganglion cell degeneration in glaucoma: an opportunity missed?A review. Clin. Experiment. Ophthalmol. 40, 364368.

14. Agostinone J, Polo A Di. Retinal ganglion cell dendrite pathology and synapse loss : implications for glaucoma [Internet]. 1st ed. New Trends in Basic and Clinical Research of Glaucoma: A Neurodegenerative Disease of the Visual Sys. Elsevier B.V.; 1-18 p. Available from: http://dx.doi.org/10.1016/bs.pbr.20 15.04 .012

15. Ghasemi R, Haeri A, Dargahi L, Mohamed Z, Ahmadiani A. Insulin in the brain: sources, localization and functions. Mol Neurobiol 2013; 47: 145-71.

16. Athauda D, Foltynie T. Insulin resistance and Parkinson's disease: a new target for disease modification? Prog Neurobiol 2016; 145-6: 98-120.

17. Song BJ, Aiello LP, Pasquale LR. Presence and risk factors for glaucoma in patients with diabetes. Curr Diab Rep 2016; 16: 124.

18. Bloom GS, Lazo JS, Norambuena A. Reduced brain insulin signaling: a seminal process in Alzheimer's disease pathogenesis. Neuropharmacology 2017, in press. doi:

10.1016/j.neuropharm.2017.09.016.

19. Saxton RA, Sabatini DM. mTOR signaling in growth, metabolism, and disease. Cell 2017; 168: 96076.

20. Laplante M, Sabatini DM. Cell 2012; 149:274-293

21. Sarbassov DD, Ali SM, Kim DH, Guertin DA, Latek RR, ErdjumentBromage $\mathrm{H}$, Tempst $\mathrm{P}$, Sabatini DM. Rictor, a novel binding partner of mTOR, defines a rapamycininsensitive and raptorindependent pathway that regulates the cytoskeleton. Current biology: CB. 2004; 14:1296-1302. [PubMed: 15268862]

22. Xuemin Wang, Christopher G Proud. (2016). mTORC2 is a 
AL-IQRA MEDICAL JOURNAL : JURNAL BERKALA ILMIAH KEDOKTERAN

e-ISSN : 2549-225X. Vol. 1 No. 2, Agustus 2018, Hal. 74-83

tyrosine kinase. Cell Research , 26:

$1-2$. 